\title{
KOMPARASI METODE STANDARD SETTING UNTUK PENENTUAN KKM MATA PELAJARAN MATEMATIKA KELAS VIII SMP
}

\author{
${ }^{1)}$ Susi Anto, ${ }^{2)}$ Djemari Mardapi \\ ${ }^{1)}$ LPMP Daerah Istimewa Yogyakarta, ${ }^{2)}$ Universitas Negeri Yogyakarta \\ ${ }^{1)}$ susianto.lpmpjogi@@gmail.com, ${ }^{2)}$ djemarimardapi@yahoo.co.id
}

\begin{abstract}
Abstrak
Tujuan penelitian ini adalah menemukan skor batas Kriteria Ketuntasan Minimum (KKM) dengan memanfaatkan metode yang ada dalam standard setting. Metode yang digunakan adalah metode Extended Angoff dan metode Ebel. Penelitian ini merupakan penelitian deskriptif kuantitatif yang diperkuat dengan data kualitatif. Data kuantitatif yang digunakan dalam penelitian ini adalah pola respon peserta didik atas soal UKK SMP/MTs Kelas VIII Mapel Matematika Kabupaten Sleman 2011/2012. Selain itu, dalam penentuan cut of score, juga digunakan data kuantitatif yang diperoleh dari expert judgement. Sementara expert judgement yang bersifat kualitatif digunakan untuk menilai kualitas pelaksanaan pertemuan standard setting. Hasil penelitian ini menunjukkan bahwa cutscore yang diperoleh dengan menggunakan metode Extended Angoff maupun Ebel masing-masing 59 dan 50,98 pada skala 100. Cutscore ini berbeda cukup signifikan dengan KKM sekolah yang ditentukan dengan menggunakan metode konvensional. Berdasarkan analisis validitas standard setting, metode Extended Angoff memberikan hasil cutscore yang relatif lebih valid dibanding metode Ebel. Validitas standard setting yang diukur dalam penelitian ini adalah validitas internal yang meliputi method consistency, decision consistency, intra-judge consistency, dan inter-judge consistency.
\end{abstract}

Kata kunci: standard setting, KKM, validitas standard setting

\section{COMPARISON OF STANDARD SETTING METHOD FOR DETERMINING MINIMUM MASTERY CRITERIA}

\author{
${ }^{1)}$ Susi Anto, ${ }^{2)}$ Djemari Mardapi \\ ${ }^{1)}$ LPMP Daerah Istimewa Yogyakarta, ${ }^{2)}$ Universitas Negeri Yogyakarta \\ ${ }^{1)}$ susianto.lpmpjogja@gmail.com, ${ }^{2)}$ djemarimardapi@yahoo.co.id
}

\begin{abstract}
The objective of the research is to find cutscore of Minimum Mastery Criteria (KKM) by utilizing methods existing in standard setting. The methods used are Extended Angoff and Ebel methods. This research is quantitative descriptive one supported by qualitative data. Quantitative data used in this research are the pattern of students' responses against the problems of Mathematics at the End of the Year Examination for SMP/MTs for eight graders in Kabupaten Sleman 2011/2012. In addition, quantitative data obtained from expert judgement are also used for determining cut of score. Meanwhile, qualitative expert judgement is used to assess the quality of standard setting meeting. The result of this research shows that cutscore gained using both Extended Angoff and Ebel methods is 59 and 50,98 respectively on a scale of 100. This cutscore is significantly different from school KKM defined using conventional method. Based on analysis of standard setting, Extended Angoff method would provide cutscore result that is relatively more valid compared to Ebel. The validity of standard setting measured in this research is the internal validity including method consistency, decision consistency, intra-judge consistency, and inter-judge consistency.
\end{abstract}

Keywords: standard setting, minimum mastery criteria, standard setting validity 


\section{Pendahuluan}

Standard setting adalah proses penetapan suatu titik dalam skala skor tes tertentu yang digunakan untuk menentukan level performa suatu kebijakan atau untuk membuat klasifikasi (Sireci dalam Wells, 2007). Dalam dunia pendidikan, standard setting banyak digunakan untuk menentukan skor batas kelulusan atau biasa disebut sebagai skor minimum kelulusan. Namun lebih dari itu, standard setting sesungguhnya dapat digunakan sebagai alat bantu untuk memetakan mutu pendidikan, sebab dengan standard setting kita bisa membuat suatu klasifikasi rendah-sedang-tinggi kompetensi seseorang atau prestasi suatu wilayah tertentu (Athanasou dan Lamprianou, 2009, p.272).

Secara garis besar, standard setting dibedakan menjadi dua golongan. Pertama yang menggunakan acuan norma sementara kedua yang menggunakan acuan kriteria. Dalam interpretasi nilai beracuan norma, kemampuan peserta tes diperbandingkan dengan kemampuan orang lain dalam kelompok acuan. Sementara dalam interpretasi nilai beracuan kriteria, kemampuan peserta tes diperbandingkan dengan level kemampuan tertentu (Reynolds, Livingston, dan Willson, 2010, pp.62-64).

Penentuan skor minimal kelulusan di Indonesia belum menerapkan kedua pendekatan di atas, tapi ditetapkan berdasarkan kesepakatan dan masukan dari lapangan. Begitu pula dalam menilai ketuntasan suatu mata pelajaran. Penentuan Kriteria Ketuntasan Minimum (KKM) selama ini dilakukan oleh masing-masing sekolah dengan menggunakan metode di luar standard setting atau ditetapkan oleh Dinas Pendidikan di tingkat kabupaten/kota dengan tujuan tertentu yang terkadang justru kontraproduktif dengan tujuan pendidikan secara luas.

Dalam hal penentuan KKM, metode yang selama ini dikenal oleh guru adalah dengan menentukan subskornya berdasarkan intake siswa, daya dukung, dan kompleksitas. Dari ketiga subskor tersebut selanjutnya diambil rata-rata yang kemudian digunakan sebagai KKM. Penggunaan teknik ini tentu menimbulkan masalah yang cukup serius terutama berkenaan dengan masalah reliabilitas, sebab menentukan nilai intake siswa, daya dukung, dan kompleksitas membawa konsekuensi tingginya variabilitas nilai yang mungkin muncul dari para penilai. Permasalahan reliabilitas ini bisa dieliminasi, bahkan dianulir jika KKM ditentukan dengan menggunakan standard setting.

Penelitian ini memilih metode Extended Angoff dan Ebel dengan alasan sebagai berikut. Pertama, metode ini relatif mudah jika diterapkan pada guru. Kedua, metode ini tidak memerlukan persyaratan analisis butir yang rumit, tetapi cukup dengan menggunakan teori tes klasik yang sudah cukup dikenal di kalangan para guru.

Penelitian ini bertujuan untuk: (1) mengetahui karakteristik perangkat soal UKK jenjang SMP/MTs kelas VIII mata pelajaran Matematika Kabupaten Sleman tahun pelajaran 2011/2012, (2) mengetahui skor KKM bidang studi Matematika untuk siswa SMP/MTs kelas VIII di Kabupaten Sleman jika ditentukan dengan menggunakan metode standard setting berbasis tes (testcentered) yaitu metode Extended Angoff dan metode Ebel, (3) mengetahui persentase ketuntasan siswa kelas VIII jenjang SMP/MTs untuk mata pelajaran Matematika di Kabupaten Sleman jika menggunakan KKM yang ditentukan dengan metode Extended Angoff dan metode Ebel, (4) mengetahui deskripsi kemampuan siswa kelas VIII jenjang SMP/ MTs di Kabupaten Sleman untuk mata pelajaran Matematika yang telah dikatakan tuntas jika menggunakan skor KKM berdasarkan metode Extended Angoff, (5) membuat interpretasi terhadap perbedaan skor KKM yang dihasilkan dengan menggunakan metode standard setting yang berbeda, (6) mengetahui metode yang mampu menghasilkan cutscore dengan validitas terbaik, (7) mengetahui kompatibilitas metode Extended Angoff dan metode Ebel bagi para guru untuk menentukan KKM, dan (8) mengetahui metode yang lebih mudah dalam penentuan KKM diantara 2 metode yaitu metode konvensional dan metode standard setting (Extended Angoff dan Ebel). 


\section{Metode Penelitian}

Penelitian ini merupakan penelitian deskriptif kuantitatif yang diperkuat dengan data kualitatif. Data kuantitatif yang digunakan dalam penelitian ini adalah pola respon peserta didik atas soal UKK SMP/ MTs Kelas VIII Mapel Matematika Kabupaten Sleman 2011/2012. Selain itu, dalam penentuan cut of score, juga digunakan data kuantitatif yang diperoleh dari expert judgement. Sementara expert judgement yang bersifat kualitatif digunakan untuk menilai kualitas pelaksanaan pertemuan standard setting.

Penelitian ini mengambil tempat di Kabupaten Sleman. Alasan penentuan lokasi penelitian ini adalah: (1) Sleman memiliki wilayah yang cukup luas, (2) Sleman memiliki kondisi sosial ekonomi yang cukup lengkap yang mewakili tiga kondisi yang berbeda, yaitu urban, suburban, dan rural.

Penelitian dilaksanakan pada bulan April hingga Agustus 2012. Serangkaian kegiatan persiapan dilakukan pada bulan April 2012, sementara pengambilan data respon siswa dilakukan pada bulan Juni 2012. Pada bulan Juli 2012 dilakukan analisis butir soal berdasarkan data respon siswa untuk mengetahui karakteristik perangkat tes. Kegiatan selanjutnya adalah pengambilan data kuantitatif dan kualitatif melalui panel bersama expert dalam bentuk focused group discussion (FGD) yang dilaksanakan pada bulan Agustus 2012.

Data set dalam penelitian ini berupa respon peserta didik SMP/MTs kelas VIII Kabupaten Sleman tahun pelajaran 2011/ 2012 sebanyak 3504 siswa. Siswa tersebut terdistribusi dalam $24 \mathrm{SMP} / \mathrm{MTs}$ yang dipilih mengikuti distribusi perolehan nilai UKK jenjang SMP/MTs kelas VIII Kabupaten Sleman tahun pelajaran 2011/2012 bidang studi Matematika. Dengan demikian, sekolah yang dipilih sebagai sampel mewakili kelompok-kelompok perolehan nilai baik tinggi, sedang, maupun rendah.
Tabel 1. Sumber Data Penentuan KKM Menggunakan Metode Extended Angoff

\begin{tabular}{llcc}
\hline No & Sekolah & $\begin{array}{r}\text { Jumlah } \\
\text { siswa }\end{array}$ & $\begin{array}{c}\text { Nilai } \\
\text { Rata- } \\
\text { Rata }\end{array}$ \\
\hline 1 & SMPN 1 Godean & 129 & 8,35 \\
2 & SMPN 1 Minggir & 201 & 6,22 \\
3 & SMPN 1 Mlati & 143 & 5,08 \\
4 & SMPN 2 Pakem & 104 & 4,51 \\
5 & SMPN 1 Berbah & 108 & 4,41 \\
6 & SMPN 2 Ngemplak & 207 & 4,16 \\
7 & SMPN 1 Ngaglik & 203 & 3.80 \\
8 & MTsN Godean & 146 & 3,67 \\
9 & SMPN 2 Moyudan & 188 & 3,41 \\
10 & MTsN Tempel & 160 & 3,25 \\
11 & SMPN 3 Turi & 89 & 3,02 \\
12 & SMP Muh. 1 Gamping & 85 & 2,76 \\
& Jumlah & 1763 & 52,64 \\
& Nilai rata-rata sampel & & 4,39 \\
\hline & Nilai rata-rata populasi & & 4,36 \\
\hline
\end{tabular}

Sumber data kuantitatif dalam penelitian ini dapat dilihat pada Tabel 1 dan Tabel 2. Selain pertimbangan pola distribusi skor siswa, pemilihan sekolah sampel juga memperhatikan letak sekolah secara geografis. Dengan pertimbangan tersebut diharapkan sampel merepresentasikan seluruh kondisi daerah yang ada, baik secara geografi maupun secara sosial ekonomi. Secara geografi, sampel diharapkan mampu mewakili wilayah Sleman Barat, Sleman Tengah, dan Sleman Timur. Sementara secara sosial ekonomi, sampel diharapkan mampu mewakili daerah urban, suburban, maupun rural. 
Tabel 2. Sumber Data Penentuan KKM Menggunakan Metode Ebel

\begin{tabular}{|c|c|c|c|}
\hline No & Sekolah & $\begin{array}{l}\text { Jumlah } \\
\text { Siswa }\end{array}$ & $\begin{array}{l}\text { Nilai } \\
\text { Rata- } \\
\text { Rata }\end{array}$ \\
\hline 1 & SMPN 4 Pakem & 119 & 7,86 \\
\hline 2 & SMPN 1 Turi & 108 & 6,24 \\
\hline 3 & SMPN 2 Kalasan & 211 & 5,21 \\
\hline 4 & SMPN 4 Ngaglik & 140 & 5,02 \\
\hline 5 & SMPN 1 Cangkringan & 143 & 4,74 \\
\hline 6 & SMP Muh. 3 Depok & 136 & 4,03 \\
\hline 7 & SMPN 3 Mlati & 140 & 3,64 \\
\hline 8 & SMPN 2 Gamping & 206 & 3,64 \\
\hline 9 & SMP Muh. 1 Berbah & 100 & 3,50 \\
\hline 10 & SMP Muh. 1 Minggir & 169 & 3,29 \\
\hline 11 & MTsN Seyegan & 202 & 3,25 \\
\hline 12 & $\begin{array}{l}\text { SMP Muh. } 2 \\
\text { Gamping }\end{array}$ & 69 & 2,24 \\
\hline & Jumlah & 1743 & 52,65 \\
\hline \multicolumn{3}{|c|}{ Nilai rata-rata sampel } & 4,39 \\
\hline \multicolumn{3}{|c|}{ Nilai rata-rata populasi } & 4,36 \\
\hline
\end{tabular}

Sumber data kualitatif dan kuantitatif lainnya adalah guru-guru pengampu bidang studi Matematika kelas VIII yang bertugas di $24 \mathrm{SMP} / \mathrm{MTs}$ yang digunakan sebagai sampel data set yang memenuhi kualifikasi tertentu. Kualifikasi dimaksud berkenaan dengan latar belakang pendidikan dan pengalaman mengajar guru yang bersangkutan. Guru-guru yang ditunjuk sebagai panelis harus memiliki latar belakang pendidikan yang sesuai dan memiliki pengalaman mengajar bidang studi Matematika jenjang SMP/MTs sekurang-kurangnya 10 tahun dan sekurang-kurangnya 5 tahun terakhir mengampu pelajaran Matematika di kelas VIII.

Banyaknya panelis yang digunakan dalam penelitian ini untuk masing-masing metode adalah 12 untuk menjaga agar validitas intra judge dan inter judge tetap tinggi (Fowell, S.L., Fewtrell, R., \& McLaughlin, P.J., 2008, p.11). Selain itu, panelis untuk metode Angoff dibedakan dengan panelis untuk metode Ebel untuk menghindarkan bias dan interferensi dalam estimasi mereka.

Data yang diperlukan dalam penelitian ini dikumpulkan dengan menggunakan teknik dokumentasi dan melalui focused group discussion (FGD). Instrumen pengumpul data yang digunakan adalah lembar jawab siswa, lembar kerja panelis, dan angket panelis.

Karakteristik perangkat tes perlu dianalisis terlebih dahulu untuk memutuskan apakah butir-butir yang ada memenuhi syarat untuk digunakan sebagai basis penentuan cutscore. Untuk mengetahui karakteristik butir, respon jawaban peserta akan dikaji secara kuantitatif melalui analisis empirik dengan mengacu pada teori tes klasik. Perangkat bantu yang digunakan dalam analisis tersebut adalah program Iteman versi 3.0.

Selanjutnya untuk menentukan cutscore, penelitian ini menggunakan dua metode, yaitu metode Extended Angoff dan metode Ebel. Impara dan Plake dalam Stahl (2008, p.7) mengusulkan suatu modifikasi untuk lebih menyederhanakan proses pada metode Original Angoff. Modifikasi tersebut mengusulkan agar panelis memutuskan apakah peserta ujian secara individual mampu atau tidak mampu menjawab butir soal dengan benar. Cara ini dinamakan prosedur $\mathrm{Ya} /$ Tidak. Jawaban diskor 1 bila Ya dan diskor 0 jika Tidak. Skor yang diperoleh dari tiap butir soal pada masing-masing panelis kemudian dijumlahkan. Hasil penjumlahan itu merupakan kriteria kelulusan minimum atau minimum passing level dari panelis. Nilai ratarata minimum passing level dari masing-masing panelis inilah yang merupakan final cutting score perangkat tes. 
Metode kedua yang digunakan dalam penelitian ini adalah metode Ebel. Metode yang dikemukakan Ebel mengusulkan suatu prosedur yang mirip dengan Angoff, namun dengan pertimbangan keterkaitan menyangkut relevansi isi tiap butir dan tingkat kesukarannya dapat mempengaruhi pertimbangan tentang bagaimana kualifikasi minimal peserta tes yang diharapkan untuk mengerjakan suatu butir (Ebel, 1979, p.340). Teknik ini menggunakan suatu jaringan dua dimensi untuk membuat kategori setiap butir. Dimensi satu menyangkut tingkat relevansi isi butir, sementara dimensi dua menyangkut tingkat kesukaran butir. Tingkat relevasi butir dibedakan menjadi empat kategori yang meliputi essential (sangat penting), important (penting), acceptable (dapat diterima), dan questionable (dipertanyakan). Tingkat kesukaran dibedakan menjadi tiga kategori yang meliputi mudah, sedang, dan sulit.

Setelah cutscore ditentukan, langkah selanjutnya adalah menganalisis persentase dan deskripsi ketuntasan siswa kelas VIII jenjang SMP/MTs di Kabupaten Sleman untuk mata pelajaran Matematika. Analisis ini penting karena beberapa alasan. Pertama, untuk mengetahui peta pencapaian siswa kelas VIII jenjang SMP/MTs di Kabupaten Sleman dalam pembelajaran Matematika. Kedua, untuk membantu membuat proyeksi persentase kelulusan siswa kelas VIII jenjang SMP/MTs di Kabupaten Sleman setahun yang akan datang pada mata pelajaran Matematika. Ketiga, untuk membantu membuat proyeksi terhadap deskripsi kemampuan yang betul-betul sudah dikuasai siswa atau masih perlu upaya keras baik oleh guru maupun siswa untuk menguasainya. Keempat, untuk membuat penilaian terhadap estimasi panelis tentang kemampuan siswa-siswinya, apakah estimasi tersebut sudah tepat ataukah under atau bahkan over-estimate.

Validitas cutscore yang dihasilkan juga akan dihitung untuk menentukan cutscore manakah dari kedua metode yang digunakan (Extended Angoff dan Ebel) yang memiliki tingkat validitas terbaik. Validitas cutscore akan diukur melalui validitas internal yang meliputi: method consistency, decision consistency, intra-judge consistency, dan inter-judge consistency.

Konsistensi metode akan diukur melalui standard error of judgement (SEj) atau kesalahan baku penjurian (Norcini et al., 1987, p.60). Menurut Cohen et al., (1999, p.362), konsistensi metode dapat dikatakan memenuhi jika nilai SEj sama dengan atau lebih kecil dari setengah nilai standar error of measurement (SEM) tes.

Konsistensi keputusan akan diukur dengan menggunakan persamaan:

$$
|Z|=\left(C_{x}-M-0,5\right) / S_{x}
$$

Artinya $C_{x}$ adalah cutscore tes, $M$ adalah rata-rata skor peserta tes, dan $\mathrm{S}_{\mathrm{x}}$ adalah simpangan baku skor peserta tes (Cizek \& Bunch, 2007, p.307). Harga mutlak Z kemudian digunakan untuk menentukan estimasi koefisien kesepakatan $\left(\mathrm{p}_{0}\right)$ dan nilai kappa (k) dari dua tabel Subkoviak yang tercantum pada Cizek \& Bunch (2007, pp.310-311). Semakin tinggi koefisien kesepakatan $\left(\mathrm{p}_{0}\right)$ maka semakin tinggi pula proporsi keputusan konsisten yang diharapkan jika prosedur pengujian ulang dilakukan. Begitu pula semakin besar nilai kappa $(\mathrm{k})$ mengindikasikan makin besarnya pengaruh prosedur pengujian terhadap konsistensi keputusan. Rendahnya nilai kappa (k) menunjukkan bahwa cutscore yang dihasilkan terletak jauh dari area distribusi skor dengan tingkat densitas tertinggi dan estimasi reliabilitas tes rendah (Cizek \& Bunch, 2007, p.312).

Intra-judge consistency yang akan diukur adalah intra-judge consistency baik di dalam putaran maupun antar putaran. Intra-judge consistency across rounds akan dilihat dari magnitudo perubahan rating butir dari putaran ke putaran dan banyaknya rating butir yang berubah dari putaran ke putaran (Loomis et al., 2000, p.13). Intra-judge consistency within rounds akan ditentukan berdasarkan pemetaaan keputusan rating setiap butir pada tabel tingkat kesulitan item (Loomis et al., 2000, p.15). Pemetaan itu akan diuji melalui nilai korelasinya. Nilai korelasi yang tinggi mengindikasikan tingkat konsistensi 
yang memuaskan. Jika diestimasi bahwa tingkat kesulitan empiriknya tinggi -bahkan untuk panelis yang telah expert sekalipun, maka nilai korelasi di atas 0,30 sudah dianggap memuaskan (Alderson, 1993, p.55).

Inter-judge consistency merupakan kriteria yang penting untuk menilai apakah suatu proses standard setting memiliki alasan yang cukup memadai atau tidak (Loomis et al., 2000, p.13). Inter-judge consistency akan dilihat dari simpangan baku cutscore. Secara umum simpangan baku antar putaran akan semakin mengecil untuk cutscore pada level cakap dan ahli, dan akan membesar untuk cutscore pada level dasar (Loomis et al., 2000, p.13).

Untuk menjawab pertanyaan apakah metode Extended Angoff dan metode Ebel cukup kompatibel digunakan oleh guru untuk menentukan KKM serta pertanyaan apakah metode Extended Angoff dan metode Ebel lebih mudah digunakan untuk menentukan KKM jika dibandingkan dengan metode konvensional akan digunakan analisis statistik deskriptif. Data yang dianalisis merupakan feedback panelis atas penyelengaraan pertemuan standard setting yang telah dilakukan. Data tersebut diperoleh dari respon panelis atas instrumen angket yang disebarkan setelah putaran penentuan standard setting dilakukan.

\section{Hasil Penelitian dan Pembahasan}

Sebagaimana telah diungkap pada bagian sebelumnya, karakteristik butir soal perangkat tes perlu diketahui terlebih dahulu sebelum digunakan dalam penentuan cutscore. Karakteristik butir tersebut digunakan sebagai dasar keputusan apakah instrumen tes dimaksud memenuhi syarat atau tidak untuk digunakan sebagai basis penentuan cutscore, sebab kelayakan instrumen menjadi prasyarat utama yang harus dipenuhi dalam penentuan cutscore yang berbasiskan alat tes (test-centered models).

Penentuan cutscore yang berbasiskan alat tes (test-centered models) mengasumsikan bahwa perangkat tes yang digunakan adalah perangkat tes yang terstandar. Definisi terstandar ini mencakup terstandar tahapan penyusunannya, terstandar cakupan dan kedalaman materinya, maupun terstandar karakteristik tiap butir penyusunnya.

Dilihat dari sisi tahapan penyusunannya, perangkat tes dimaksud sudah bisa dikatakan terstandar karena disusun melalui prosedur yang telah terstandar oleh tim di bawah Musyawarah Kerja Kepala Sekolah (MKKS) jenjang SMP/MTs di Kabupaten Sleman. Begitu pula dari sisi cakupan dan kedalaman materinya, perangkat tes dimaksud juga sudah bisa dikatakan terstandar karena disusun berdasarkan SK dan KD yang sesuai dengan kelas dan jenjangnya sebagaimana termaktub dalam Standar Isi. Sementara dari karakteristik tiap butir penyusunnya, perlu dilakukan analisis untuk menyimpulkan apakah perangkat tes tersebut sudah bisa dikatakan terstandar atau belum.

Berdasarkan analisis butir menggunakan program Iteman tersebut, diperoleh kesimpulan bahwa seluruh butir yang terdapat dalam instrumen tes dapat digunakan dalam penentuan cutscore, karena semua indikator memberikan informasi yang bagus. Indikator-indikator itu adalah tingkat kesulitan butir, daya beda butir, efektivitas distraktor, dan keberfungsian kunci jawaban.

\section{Metode Extended Angoff}

Putaran pertama metode Extended Angoff menghasilkan cutscore sebesar 23 butir benar dari 40 butir soal UKK atau sebesar $58 \%$. Dengan menggunakan final cutscore 1 ini sebagai KKM, ternyata ada $22 \%$ siswa di sekolah sampel yang bisa dikatakan telah tuntas dalam mengikuti materi pembelajaran matematika SMP/MTs kelas VIII. Sementara pada putaran kedua, menghasilkan cutscore sebesar 24 butir benar dari 40 butir soal UKK atau sebesar 60\%. Dengan menggunakan final cutscore 2 ini sebagai KKM, tingkat ketuntasan turun menjadi 19\%. 
Tabel 3. Rekapitulasi Cutscore Metode Extended Angoff

\begin{tabular}{|c|c|c|c|c|c|c|}
\hline \multirow{3}{*}{$\begin{array}{c}\text { No. Panelis } \\
1\end{array}$} & \multicolumn{4}{|c|}{ Cutscore Panelis } & \multirow{2}{*}{\multicolumn{2}{|c|}{ Perubahan Keputusan }} \\
\hline & \multicolumn{2}{|c|}{ Putaran 1} & \multicolumn{2}{|c|}{ Putaran 2} & & \\
\hline & 19 & $48 \%$ & 20 & $50 \%$ & 1 & $2,5 \%$ \\
\hline 2 & 14 & $35 \%$ & 15 & $38 \%$ & 1 & $2,5 \%$ \\
\hline 3 & 25 & $63 \%$ & 26 & $65 \%$ & 1 & $2,5 \%$ \\
\hline 4 & 24 & $60 \%$ & 23 & $58 \%$ & 1 & $2,5 \%$ \\
\hline 5 & 23 & $58 \%$ & 23 & $58 \%$ & 0 & $0,0 \%$ \\
\hline 6 & 22 & $55 \%$ & 27 & $68 \%$ & 5 & $12,5 \%$ \\
\hline 7 & 25 & $63 \%$ & 28 & $70 \%$ & 3 & $7,5 \%$ \\
\hline 8 & 23 & $58 \%$ & 25 & $63 \%$ & 2 & $5,0 \%$ \\
\hline 9 & 22 & $55 \%$ & 20 & $50 \%$ & 2 & $5,0 \%$ \\
\hline 10 & 24 & $60 \%$ & 24 & $60 \%$ & 0 & $0,0 \%$ \\
\hline 11 & 31 & $78 \%$ & 31 & $78 \%$ & 0 & $0,0 \%$ \\
\hline 12 & 24 & $60 \%$ & 26 & $65 \%$ & 2 & $5,0 \%$ \\
\hline Rata-Rata & 23 & $58 \%$ & 24 & $60 \%$ & 1,5 & $3,75 \%$ \\
\hline KKM Final & \multicolumn{2}{|c|}{23,5} & \multicolumn{2}{|c|}{$59 \%$} & & \\
\hline
\end{tabular}

Tabel 3 menampilkan rekapitulasi cutscore para panelis pada putaran pertama dan kedua metode Extended Angoff. Rata-rata estimasi para panelis pada putaran pertama dan kedua menunjukkan perbedaan angka yang sudah dapat diterima yaitu 1,5 butir dari 40 butir soal $(3,75 \%)$. Oleh karena itu tidak diperlukan adanya putaran ketiga pada metode Extended Angoff ini.

Tabel 4. Hasil Penentuan KKM Bidang Studi Matematika Jenjang SMP/ MTs Kelas VIII di Kabupaten Sleman Menggunakan Metode Extended Angoff

\begin{tabular}{ccccc}
\hline \multirow{5}{*}{ Banyak } & Persentase Banyak Persentase \\
& $\begin{array}{c}\text { Butir } \\
\text { Benar }\end{array}$ & $\begin{array}{c}\text { Butir } \\
\text { Benar }\end{array}$ & $\begin{array}{c}\text { Siswa } \\
\text { Tuntas }\end{array}$ & $\begin{array}{c}\text { Siswa } \\
\text { Tuntas }\end{array}$ \\
\hline Pertama & 23 & $58 \%$ & 765 & $22 \%$ \\
Kedua & 24 & $60 \%$ & 682 & $19 \%$ \\
\hline Rata-Rata & 23,5 & $59 \%$ & 682 & $19 \%$ \\
\hline
\end{tabular}

KKM sesungguhnya diperoleh dengan mengambil rata-rata cutscore dari putaran pertama dan kedua. Tabel 4 menunjukkan skor KKM akhir sebesar 59\%. De- ngan menggunakan KKM ini, ada 682 dari 3504 (sekitar 19\%) siswa di sekolah sampel yang bisa dikatakan telah tuntas dalam mengikuti materi pembelajaran matematika SMP/MTs kelas VIII.

Setelah menentukan cutscore pada putaran pertama, para panelis mendiskusikan deskriptor dari cutscore yang ditetapkan dengan metode Extended Angoff. Deskriptor yang digunakan merupakan kompetensi yang diukur oleh tiap butir soal hasil diskusi dan disesuaikan dengan frekuensi panelis yang menjawab Ya. Hasil diskusi menunjukkan ada 38 deskriptor yang memperoleh minimal 1 jawaban Ya dari panelis. Itu berarti populasi siswa yang telah melampaui skor KKM atau siswa yang telah tuntas dapat dikatakan setidaknya memiliki 38 kompetensi sebagaimana diukur oleh ke-38 butir tersebut.

Metode Ebel

Putaran pertama metode Ebel menghasilkan cutscore sebesar 19,93 atau 49,82 pada skala 100. Dengan menggunakan final cutscore 1 ini sebagai KKM, ada 32\% siswa di sekolah sampel yang bisa dikatakan telah tuntas dalam mengikuti materi pembelajar- 
an Matematika SMP/MTs kelas VIII. Sementara pada putaran kedua, penentuan cutscore dengan metode Ebel menghasilkan cutscore sebesar 20,85 atau 52,13 pada skala 100. Dengan menggunakan final cutscore 2 ini sebagai KKM, tingkat ketuntasan menurun menjadi $28 \%$.

Tabel 5 menampilkan rekapitulasi cutscore para panelis pada putaran pertama dan kedua metode Ebel. Rata-rata estimasi para panelis pada putaran pertama dan kedua menunjukkan perbedaan angka yang sudah dapat diterima yaitu 1,82 butir dari 40 butir soal $(4,55 \%)$. Oleh karena itu tidak diperlukan adanya putaran ketiga pada metode Ebel ini.

Tabel 5. Rekapitulasi Cutscore Metode Ebel

\begin{tabular}{ccccccc}
\hline \multirow{2}{*}{ No. Panelis } & \multicolumn{3}{c}{ Cutscore Panelis } & & \\
\cline { 2 - 3 } 1 & \multicolumn{2}{c}{ Putaran 1} & \multicolumn{2}{c}{ Putaran 2} & & \\
2 & 14,4 & $36,0 \%$ & 17,4 & $43,5 \%$ & 3,00 & $7,5 \%$ \\
3 & 24,6 & $61,5 \%$ & 27,5 & $68,8 \%$ & 2,90 & $7,3 \%$ \\
4 & 24,5 & $61,3 \%$ & 23,8 & $59,5 \%$ & 0,70 & $1,8 \%$ \\
5 & 22,1 & $55,3 \%$ & 21,9 & $54,8 \%$ & 0,20 & $0,5 \%$ \\
6 & 13,7 & $34,3 \%$ & 16,34 & $40,9 \%$ & 2,64 & $6,6 \%$ \\
7 & 14,68 & $36,7 \%$ & 14,68 & $36,7 \%$ & 0,00 & $0,0 \%$ \\
8 & 13,95 & $34,9 \%$ & 19,95 & $49,9 \%$ & 6,00 & $15,0 \%$ \\
9 & 16,35 & $40,9 \%$ & 15,5 & $38,8 \%$ & 0,85 & $2,1 \%$ \\
10 & 18,25 & $45,6 \%$ & 18 & $45,0 \%$ & 0,25 & $0,6 \%$ \\
11 & 25,1 & $62,8 \%$ & 22 & $55,0 \%$ & 3,10 & $7,8 \%$ \\
12 & 35 & $87,5 \%$ & 34,75 & $86,9 \%$ & 0,25 & $0,6 \%$ \\
Rata-Rata & 16,5 & $41,3 \%$ & 18,4 & $46,0 \%$ & 1,90 & $4,8 \%$ \\
KKM Final & 19,93 & $49,8 \%$ & 20,85 & $52,13 \%$ & 1,82 & $4,55 \%$ \\
\hline
\end{tabular}

Tabel 6 memberi informasi yang lengkap hasil perhitungan KKM dengan menggunakan metode Ebel berikut persentase tingkat ketuntasan siswa di sekolah sampel. KKM sesungguhnya diperoleh dengan mengambil rata-rata skor KKM pada putaran pertama dan kedua. Dari nilai ratarata itu diperoleh KKM akhir sebesar $50,97 \%$. Dengan menggunakan KKM ini, ada 972 dari 3504 (sekitar 28\%) siswa di sekolah sampel yang bisa dikatakan telah tuntas dalam mengikuti materi pembelajaran matematika SMP/MTs kelas VIII.
Tabel 6. Hasil Penentuan KKM Bidang Studi Matematika Jenjang SMP/MTs Kelas VIII di Kabupaten Sleman Menggunakan Metode Ebel

\begin{tabular}{ccccc}
\hline & & & & \\
Putaran & Skor & Persentase & Banyak & Persentase \\
& KKM & Skor & Siswa & Siswa \\
& & KKM & Tuntas & Tuntas \\
\hline Pertama & 19,93 & $49,82 \%$ & 1134 & $32 \%$ \\
Kedua & 20,85 & $52,13 \%$ & 972 & $28 \%$ \\
Rata-Rata & 20,39 & $50,97 \%$ & 972 & $28 \%$ \\
\hline
\end{tabular}


Metode Extended Angoff dan Ebel pada penelitian ini masing-masing menghasilkan nilai cutscore 59 dan 50,98 pada skala 100. Ini berarti kedua metode menghasilkan nilai cutscore yang berbeda. Perbedaan itu muncul sebagai implikasi logis dari perbedaan konsep yang melatarbelakangi metode-metode tersebut. Beberapa hal yang bisa diuraikan untuk menjelaskan perbedaan itu adalah sebagai berikut.

Pertama, pada metode Extended Angoff, baik tingkat kesulitan soal maupun tingkat kemampuan peserta tes berpengaruh secara dependen satu sama lain terhadap keputusan Ya/Tidak panelis. Sementara pada metode Ebel tingkat kesulitan soal dan tingkat kemampuan peserta tes berpengaruh secara independen satu sama lain terhadap keputusan panelis. Selain itu di samping tingkat kesulitan soal, pada metode Ebel ada juga parameter lain yang ikut berpengaruh terhadap keputusan panelis yaitu tingkat relevansi soal. Pada metode Ebel tingkat kesulitan dan tingkat relevansi butir berpengaruh pada keputusan jumlah butir yang tersarang dalam tiap-tiap sel. Sementara tingkat kemampuan peserta tes berpengaruh kepada persentase jawaban benar yang tersarang dalam tiap-tiap sel.

Kedua, metode Ebel membutuhkan lebih banyak estimasi dibanding metode Extended Angoff. Jika pada metode Extended Angoff panelis hanya diminta mem-buat satu jenis estimasi, maka tidak demikian halnya pada metode Ebel. Sebab ada tiga parameter yang mesti diestimasi oleh para panelis pada metode Ebel. Parameter itu adalah tingkat kesulitan butir, tingkat relevansi butir, dan tingkat kemampuan peserta tes. Banyaknya parameter yang mesti diestimasi ini akan berbanding lurus dengan banyaknya keraguan yang mungkin muncul dari para panelis. Semakin banyak parameter yang mesti diestimasi, semakin tinggi pula frekuensi munculnya ragu panelis.

Ketiga, nilai proporsi metode Extended Angoff bisa dikatakan lebih detail dibanding metode Ebel. Sebab pada metode Extended Angoff proporsi ditentukan untuk setiap butirnya sementara pada metode Ebel, nilai proporsi ditentukan untuk setiap selnya. Hal ini membawa implikasi nilai proporsi pada metode Ebel lebih bias dibanding nilai proporsi pada metode $E x$ tended Angoff.

Metode Extended Angoff pada penelitian ini menghasilkan nilai cutscore 59 pada skala 100. Pada nilai cutscore 59 ini banyaknya siswa yang tuntas belajarnya adalah $19 \%$ dari 3504 siswa sampel. Sementara pa-da metode Ebel dihasilkan skor cutscore 50,98 dan tingkat ketuntasan siswa di angka $28 \%$. Rendahnya persentase ketuntasan siswa ini menunjukkan baik panelis metode Extended Angoff maupun Ebel, keduanya telah over estimate dalam memberikan penilaian atas kemampuan peserta didiknya. Jika estimasi mereka tepat, maka akan dihasilkan skor KKM yang lebih rendah dan persentase ketuntasan yang lebih tinggi.

\section{Validitas Standard Setting}

Validitas cutscore yang dihasilkan baik oleh metode Extended Angoff maupun oleh metode Ebel akan diukur melalui validitas internalnya. Validitas internal yang hendak diukur tersebut meliputi method consistency, decision consistency, intra-judge consistency, dan inter-judge consistency.

Tabel 7. Kesalahan Baku Penjurian (SEj)

Metode Extended Angoff dan Metode Ebel

\begin{tabular}{|c|c|c|c|}
\hline \multirow{2}{*}{ Putaran } & \multicolumn{2}{|c|}{ Kesalahan Baku (SEj) } & \multirow{2}{*}{$\begin{array}{c}\text { Referens } \\
\text { i }\end{array}$} \\
\hline & Ext. Angoff & Ebel & \\
\hline Pertama & 1,148 & 1,870 & $\leq 1.3885$ \\
\hline Kedua & 1,225 & 1,657 & $\leq 1.3885$ \\
\hline Putaran $1 \& 2$ & 0,828 & 1,225 & $\leq 1.3885$ \\
\hline
\end{tabular}

Konsistensi metode dapat diukur melalui standard error of judgement (SEj) atau kesalahan baku penjurian. Sebagaimana ditunjukkan oleh Tabel 7, baik pada putaran pertama maupun pada putaran kedua, nilai kesalahan baku (standard error) pada metode Ebel selalu lebih tinggi dibanding pada metode Extended Angoff. Tabel 7 juga menunjukkan bahwa nilai Sej metode Ebel baik pada putaran 1 maupun pada putaran 2 selalu di atas nilai referensi yang disyarat- 
kan yaitu setengah kali nilai SEM. Berangkat dari fenomena ini dapat dikatakan bahwa method consistency pada metode Ebel putaran 1 dan putaran 2 belum memenuhi syarat. Syarat konsistensi metode Ebel ini baru terpenuhi ketika rating cutscore individual digabung antara putaran 1 dan putaran 2. Itupun juga masih lebih besar dibanding metode Extended Angoff.

Berangkat dari premis-premis tersebut dapat disimpulkan bahwa method consistency metode Extended Angoff lebih bagus dibanding metode Ebel. Atau dengan kata lain dapat diungkapkan bahwa metode $E x$ tended Angoff mampu memberikan konsistensi penjurian yang lebih baik dibanding metode Ebel. Hal ini bisa menjadi petunjuk bahwa bias estimasi pada metode Ebel lebih tinggi dibanding pada metode Extended Angoff.

Metode Ebel memungkinkan munculnya lebih banyak kesalahan dibanding metode Extended Angoff. Hal tersebut disebabkan metode Ebel membutuhkan lebih banyak estimasi dibanding metode Extended Angoff. Banyaknya parameter yang harus diestimasi ini berbanding lurus dengan banyaknya keraguan yang mungkin muncul dari para panelis. Semakin banyak parameter yang mesti diestimasi, semakin tinggi pula frekuensi munculnya ragu panelis. Keraguan inilah yang sering membawa implikasi pada munculnya bias estimasi. Bias estimasi inilah yang terbaca pada nilai standard error sebagaimana ditunjukkan Tabel 7.

Selain itu, tingkat akurasi nilai proporsi pada metode Extended Angoff bisa dikatakan lebih tinggi dibanding pada metode Ebel. Sebab pada metode Extended Angoff proporsi ditentukan untuk setiap butirnya sementara pada metode Ebel, nilai proporsi ditentukan untuk setiap selnya. Hal ini membawa implikasi nilai proporsi pada metode Ebel lebih bias dibanding ni-lai proporsi pada metode Extended Angoff.

Konsistensi keputusan ditentukan dengan cara menghitung nilai harga mutlak $\mathrm{Z}$ terlebih dahulu. Harga mutlak $Z$ kemudian digunakan untuk menentukan estimasi koefisien kesepakatan $\left(\mathrm{p}_{0}\right)$ dan nilai kappa $(\mathrm{k})$ dari dua tabel Subkoviak. Tabel 8 menunjukkan harga $|Z|$, alpha, $p_{0}$, dan $\mathrm{k}$ untuk masing-masing metode dan masing-masing putaran. Berdasarkan tabel Subkoviak nilai maksimum $\mathrm{p}_{0}$ adalah 0,98 dan nilai maksimum untuk $\mathrm{k}$ adalah 0,71 . Oleh karena itu dapat disimpulkan bahwa berdasar Tabel 8, konsistensi keputusan kedua metode pada penelitian ini sudah cukup memuaskan seperti ditunjukkan oleh harga $\mathrm{p}_{0}$ dan $\mathrm{k}$.

Sebagaimana diketahui bahwa semakin tinggi koefisien kesepakatan $\left(\mathrm{p}_{0}\right)$ maka semakin tinggi pula proporsi keputusan konsisten yang diharapkan jika prosedur pengujian ulang dilakukan. Oleh karena itu, harga $\mathrm{p}_{0}$ yang di atas 0,8 (maksimum 0,98 ) menunjukkan bahwa munculnya proporsi keputusan konsisten yang diharapkan cukup tinggi jika prosedur pengujian ulang dilakukan baik pada metode Extended Angoff maupun pada metode Ebel. Tabel 8 juga menunjukkan bahwa nilai $\mathrm{p}_{0}$ metode Extended Angoff selalu lebih tinggi dibanding Ebel baik itu pada putaran 1, putaran 2, maupun gabungan putaran 1 dan 2 . Hal ini mengindikasikan bahwa harapan munculnya proporsi keputusan yang konsisten jika pengujian ulang dilakukan selalu lebih tinggi pada metode Extended Angoff dibanding pada Metode Ebel.

Tabel 8. Nilai Koefisien Kesepakatan $\left(\mathrm{p}_{0}\right)$ dan Kappa (k) Metode Extended Angoff dan Metode Ebel

\begin{tabular}{lcccccc}
\hline & \multicolumn{3}{c}{ Extended Angoff } & \multicolumn{3}{c}{ Ebel } \\
\cline { 2 - 7 } & Put. 1 & Put. 2 & Total & Put. 1 & Put. 2 & Total \\
\hline$|Z|$ & 0.67 & 0,81 & 0,74 & 0,25 & 0,38 & 0,31 \\
Alpha & 0.85 & 0,85 & 0,85 & 0,85 & 0,85 & 0,85 \\
p0 & 0.86 & 0,88 & 0,87 & 0,83 & 0,84 & 0,83 \\
Kappa (k) & 0.64 & 0,62 & 0,63 & 0,65 & 0,65 & 0,65 \\
\hline
\end{tabular}


Jika diperbandingkan nilai kappanya, maka metode Extended Angoff selalu menghasilkan nilai kappa yang lebih rendah dibandingkan metode Ebel, baik pada putaran 1 , putaran 2 , maupun gabungan putaran 1 dan 2. Hal ini menunjukkan bahwa cutscore yang dihasilkan metode Extended Angoff selalu terletak lebih jauh dari area distribusi skor dengan tingkat densitas tertinggi dibanding dengan cutscore yang dihasilkan metode Ebel.

Sebagaimana telah diuraikan di depan, metode Extended Angoff dan Ebel pada penelitian ini masing-masing menghasilkan nilai cutscore 59 dan 50,98 pada skala 100. Di samping itu, berdasarkan statistik deskriptif dapat diketahui bahwa nilai skew skor tes yang dihasilkan berharga positif. Nilai skeen yang berharga positif mengindikasikan bah- wa sebagian besar skor peserta tes terletak di bagian bawah (skor rendah) dari distribusi skor. Selain itu juga diketahui bahwa nilai kurtosis skor tes berharga positif. Nilai kur-tosis yang berharga positif menunjukkan distribusi yang lebih lancip (memuncak) yang berarti sebagian besar skor peserta mengumpul di sekitar nilai modus (modus $=37,5$ ) yang condong ke sebelah kiri dari kur-va distribusi. Oleh karena itu, bisa dipahami jika nilai kappa yang dihasilkan metode Ebel selalu lebih tinggi dibanding nilai kappa yang dihasilkan metode Extended Angoff, karena cutscore yang dihasilkan metode Ebel selalu lebih dekat ke nilai modus (modus $=37,5$ ) skor peserta tes dibanding cutscore yang dihasilkan metode Extended Angoff sebagaimana ditunjukkan oleh Tabel 9.

Tabel 9. KKM Metode Extended Angoff dan Metode Ebel vs Modus Skor Tes

\begin{tabular}{ccccccc}
\hline & \multicolumn{2}{c}{ KKM Extended Angoff } & \multicolumn{2}{c}{ KKM Ebel } & \multicolumn{2}{c}{ Modus Skor Tes } \\
\cline { 2 - 6 } & Skor & n benar & Skor & n benar & Skor & n benar \\
\hline Put. 1 & 60 & 24 & 49,825 & 20 & & \\
Put. 2 & 57,5 & 23 & 52,025 & 21 & 37,5 & 15 \\
Total & 58,75 & 23,5 & 50,925 & 20,5 & & \\
\hline
\end{tabular}

Intra-judge consistency diukur melalui intra-judge consistency baik di dalam maupun antar putaran. Intra-judge consistency across rounds atau konsistensi intra-judge antarputaran dapat dilihat dari magnitudo perubahan rating cutscore individual panelis dari putaran ke putaran dan banyaknya rating butir yang berubah dari putaran ke putaran (Loomis et al., 2000, p.13). Tabel 10 menunjukkan magnitudo perubahan rating cutscore individual panelis dari putaran $1 \mathrm{ke}$ putaran 2 sementara Tabel 11 menunjukkan banyaknya butir yang rating cutscore butirnya berubah dari putaran 1 ke putaran 2. Kedua tabel tersebut menggunakan basis perhitungan banyaknya butir tes yaitu 40 .
Tabel 10 menunjukkan kepada kita bahwa magnitudo perubahan rating cutscore individual panelis dari putaran 1 ke putaran 2 metode Extended Angoff lebih kecil dibanding metode Ebel. Rata-rata perubahan untuk metode Extended Angoff adalah 1,5 $(3,75 \%)$ sementara untuk metode Ebel adalah 1,82 (4,54\%). Ini berarti pada metode Extended Angoff setiap panelis rata-rata membuat perubahan keputusan sebesar $3,75 \%$ dari keputusan sebelumnya. Sementara pada metode Ebel setiap panelis ratarata membuat perubahan keputusan sebesar 4,54\% dari keputusan sebelumnya. Angka-angka ini menunjukkan bahwa intrajudge consistency across rounds pada metode Extended Angoff lebih baik dibanding pada 
metode Ebel. Dengan kata lain panelis pada metode Extended Angoff lebih konsisten dalam membuat keputusan atau penjurian antar putaran dibanding panelis pada metode Ebel.

Tabel 10. Magnitudo Perubahan Rating Cutscore dari Putaran 1 ke Putaran 2 Metode Extended Angoff dan Metode Ebel

\begin{tabular}{ccc}
\hline & $\begin{array}{c}\text { Magnitudo Perubahan Rating } \\
\text { Cutscore (Skala 40) }\end{array}$ \\
\cline { 2 - 3 } & Ext. Angoff & Ebel \\
\hline Panelis 1 & 1 & 3 \\
Panelis 2 & 1 & 2,9 \\
Panelis 3 & 1 & 0,7 \\
Panelis 4 & 1 & 0,2 \\
Panelis 5 & 0 & 2,64 \\
Panelis 6 & 5 & 0 \\
Panelis 7 & 3 & 6 \\
Panelis 8 & 2 & 0,85 \\
Panelis 9 & 2 & 0,25 \\
Panelis 10 & 0 & 3,1 \\
Panelis 11 & 0 & 0,25 \\
Panelis 12 & 2 & 1,9 \\
Mean & 1,5 & 1.82 \\
\hline
\end{tabular}

Tabel 11 menunjukkan banyaknya butir yang rating cutscore butirnya berubah dari putaran 1 ke putaran 2. Sebagaimana Tabel 10, Tabel 11 juga menggunakan basis perhitungan banyaknya butir tes yaitu 40 . Secara umum seluruh panelis baik pada metode Extended Angoff maupun metode Ebel dapat dikatakan tidak konsisten karena melakukan perubahan terhadap keputusan butir. Hanya ada seorang panelis di metode Extended Angoff yang bisa dika- takan konsisten yaitu Panelis 10 karena dia sama sekali tidak melakukan perubahan atas keputusan butir.

Sementara itu, dibanding metode Extended Angoff konsistensi panelis pada metode Ebel bisa dikatakan lebih buruk. Hampir seluruh panelis pada metode Ebel melakukan perubahan di atas $20 \%$ dari butir yang ada. Hanya ada seorang panelis yaitu Panelis 1 yang melakukan perubahan sebanyak 1 digit. Sementara ada 4 panelis yang melakukan perubahan $50 \%$ atau lebih yaitu Panelis 3, Panelis 4, Panelis 7, dan $\mathrm{Pa}-$ nelis 10. Bahkan ada 2 panelis yang melakukan perubahan terhadap lebih dari $60 \%$ butir yang ada, yaitu Panelis 2 dan Panelis 9.

Tabel 11. Banyak Butir yang Berubah dari Putaran 1 ke Putaran 2 Metode Extended Angoff dan Metode Ebel

\begin{tabular}{ccc}
\hline & \multicolumn{2}{c}{$\begin{array}{c}\text { Banyak Butir yang } \\
\text { Berubah }\end{array}$} \\
\cline { 2 - 3 } & Ext. Angoff & Ebel \\
\hline Panelis 1 & 15 & 8 \\
Panelis 2 & 9 & 30 \\
Panelis 3 & 7 & 21 \\
Panelis 4 & 1 & 20 \\
Panelis 5 & 4 & 14 \\
Panelis 6 & 5 & 12 \\
Panelis 7 & 3 & 21 \\
Panelis 8 & 2 & 10 \\
Panelis 9 & 10 & 30 \\
Panelis 10 & 0 & 22 \\
Panelis 11 & 2 & 13 \\
Panelis 12 & 10 & 15 \\
Mean & $\mathbf{5 , 7}$ & $\mathbf{1 8}$ \\
\hline & & \\
\hline
\end{tabular}


Jika dilihat rata-ratanya banyak keputusan butir yang berubah untuk metode Extended Angoff adalah 5,7 butir (14\%) sementara untuk metode Ebel adalah 18 butir $(45 \%)$. Ini berarti pada metode $E x$ tended Angoff banyaknya butir yang berubah keputusannya pada putaran 2 untuk setiap panelis adalah $14 \%$ dari butir yang ada. Sementara pada metode Ebel banyaknya butir yang berubah keputusannya pada putaran 2 untuk setiap panelis adalah 45\% dari butir yang ada. Angka-angka ini menunjukkan bahwa intra-judge consistency across rounds pada metode Extended Angoff lebih baik dibanding pada metode Ebel. Dengan kata lain panelis pada metode Extended Angoff lebih konsisten dalam membuat keputusan atau penjurian antar putaran dibanding panelis pada metode Ebel.

Fenomena ini sekali lagi membuktikan premis yang telah dituliskan di depan bahwa banyaknya estimasi yang mesti dilakukan oleh panelis berbanding lurus dengan besarnya ragu yang mungkin muncul dari para panelis. Oleh karena itu angkaangka tersebut bisa dijelaskan dengan cara menelusuri tahapan-tahapan yang ada pada masing-masing metode. Disparitas yang cukup tinggi antara kedua metode $(14 \%$ versus $45 \%$ menunjukkan perbedaan potensi ragu yang cukup signifikan. Angka itu bisa mengatakan bahwa metode Ebel memiliki potensi ragu 3 kali lebih besar dari potensi ragu yang mungkin timbul pada metode Extended Angoff. Meski masih perlu dibuktikan lagi, tapi angka itu sebanding dengan proporsi banyaknya estimasi antara kedua metode. Jika metode Extended Angoff hanya membutuhkan satu jenis estimasi maka pada metode Ebel dibutuhkan tiga jenis estimasi.

Intra-judge consistency within rounds ditentukan berdasarkan pemetaaan keputusan rating setiap butir pada tabel tingkat kesulitan item. Pemetaan itu akan diuji melalui nilai korelasinya. Nilai korelasi yang tinggi mengindikasikan tingkat konsistensi yang memuaskan, sebaliknya nilai korelasi yang rendah mengindikasikan rendahnya konsistensi intra-judge dalam putaran.

Tabel 12 menunjukkan hasil pemetaan antara tingkat kesulitan butir statistik dan representasi tingkat kesulitan butir empirik metode Extended Angoff dan metode Ebel. Pada tabel tersebut, pemetaan dilakukan dengan terlebih dahulu mengurutkan butir berdasar tingkat kesulitannya (p) secara statistik dari mudah ke sulit. Urutan representasi tingkat kesulitan butir empirik kedua metode dibuat mengikuti urutan tingkat kesulitan butir secara statistik. Pengurutan dengan cara itu memungkinkan kita mengukur masing-masing nilai korelasinya.

Tingkat kesulitan butir statistik merupakan proporsi siswa yang menjawab benar butir tersebut yang diperoleh dari Item Analysis. Sementara representasi tingkat kesulitan butir empirik untuk metode Extended Angoff diperoleh dari banyaknya jawaban panelis yang bernilai 1 untuk tiap butirnya atau bisa juga disebut rating cutscore butir. Untuk mendapatkan representasi tingkat kesulitan butir empirik metode Ebel, terlebih dahulu butir mudah diberi skor 3 , butir sedang diberi skor 2, dan butir sulit diberi skor 1. Jumlah skor tingkat kesulitan dari semua panelis untuk setiap bu-tirnya itulah yang merupakan representasi tingkat kesulitan butir empirik untuk metode Ebel.

Tabel 12 menunjukkan adanya nilai korelasi yang cukup tinggi antara tingkat kesulitan butir statistik dan representasi tingkat kesulitan butir empirik baik pada metode Extended Angoff maupun pada metode Ebel. Keseluruhan nilai korelasi tersebut sudah jauh di atas angka yang dipersyaratkan Alderson yaitu 0,3. Ini menunjukkan bahwa para panelis baik pada metode Extended Angoff maupun metode Ebel, baik pada putaran 1 maupun putaran 2 telah memiliki nilai intra-judge consistency within rounds yang memuaskan. Atau dengan kata lain, tingkat konsistensi penjurian para panelis dalam tiap putaran sudah memuaskan. 
Tabel 12. Pemetaan Tingkat Kesulitan Butir Statistik dan Representasi Tingkat Kesulitan Butir Empirik Metode Extended Angoff dan Metode Ebel

\begin{tabular}{|c|c|c|c|c|c|c|c|}
\hline \multirow{3}{*}{ No Urut } & \multirow{3}{*}{ No Butir } & \multirow{3}{*}{$\mathrm{P}$} & \multirow{3}{*}{ Kategori } & \multicolumn{4}{|c|}{ Representasi Tingkat Kesulitan Butir Empirik } \\
\hline & & & & \multicolumn{2}{|c|}{ Putaran I } & \multicolumn{2}{|c|}{ Putaran II } \\
\hline & & & & Ext. Angf & Ebel & Ext. Angf & Ebel \\
\hline 1 & 30 & 0,844 & Mudah & 10 & 26 & 10 & 27 \\
\hline 2 & 2 & 0,840 & Mudah & 12 & 32 & 12 & 32 \\
\hline 3 & 12 & 0,737 & Sedang & 10 & 22 & 11 & 24 \\
\hline 4 & 21 & 0,720 & Sedang & 11 & 30 & 10 & 31 \\
\hline 5 & 29 & 0,627 & Sedang & 9 & 28 & 11 & 29 \\
\hline 6 & 1 & 0,623 & Sedang & 12 & 32 & 12 & 35 \\
\hline 7 & 13 & 0,598 & Sedang & 9 & 19 & 8 & 15 \\
\hline 8 & 11 & 0,572 & Sedang & 11 & 29 & 12 & 27 \\
\hline 9 & 10 & 0,563 & Sedang & 12 & 33 & 12 & 28 \\
\hline 10 & 3 & 0,550 & Sedang & 9 & 24 & 11 & 25 \\
\hline 11 & 33 & 0,536 & Sedang & 9 & 22 & 8 & 18 \\
\hline 12 & 9 & 0,517 & Sedang & 12 & 36 & 12 & 36 \\
\hline 13 & 25 & 0,484 & Sedang & 5 & 17 & 5 & 17 \\
\hline 14 & 16 & 0,483 & Sedang & 9 & 22 & 9 & 21 \\
\hline 15 & 7 & 0,451 & Sedang & 8 & 17 & 10 & 18 \\
\hline 16 & 20 & 0,478 & Sedang & 12 & 22 & 10 & 22 \\
\hline 17 & 5 & 0,451 & Sedang & 3 & 19 & 5 & 20 \\
\hline 18 & 8 & 0,416 & Sedang & 4 & 13 & 1 & 13 \\
\hline 19 & 17 & 0,408 & Sedang & 1 & 19 & 2 & 19 \\
\hline 20 & 4 & 0,407 & Sedang & 10 & 22 & 10 & 22 \\
\hline 21 & 34 & 0,405 & Sedang & 1 & 12 & 2 & 13 \\
\hline 22 & 32 & 0,402 & Sedang & 6 & 16 & 6 & 17 \\
\hline 23 & 19 & 0,384 & Sedang & 3 & 13 & 4 & 14 \\
\hline 24 & 36 & 0,377 & Sedang & 5 & 14 & 7 & 13 \\
\hline 25 & 14 & 0,369 & Sedang & 10 & 27 & 8 & 27 \\
\hline 26 & 26 & 0,349 & Sedang & 7 & 20 & 8 & 20 \\
\hline 27 & 23 & 0,339 & Sedang & 8 & 22 & 8 & 19 \\
\hline 28 & 15 & 0,333 & Sedang & 7 & 22 & 7 & 24 \\
\hline 29 & 6 & 0,332 & Sedang & 7 & 22 & 9 & 19 \\
\hline 30 & 24 & 0,325 & Sedang & 8 & 23 & 10 & 26 \\
\hline 31 & 22 & 0,305 & Sedang & 1 & 14 & 3 & 13 \\
\hline 32 & 40 & 0,303 & Sedang & 0 & 12 & 0 & 13 \\
\hline 33 & 27 & 0,300 & Sedang & 4 & 17 & 7 & 17 \\
\hline 34 & 35 & 0,295 & Sulit & 5 & 15 & 3 & 14 \\
\hline 35 & 31 & 0,276 & Sulit & 2 & 15 & 2 & 16 \\
\hline 36 & 28 & 0,270 & Sulit & 12 & 32 & 12 & 34 \\
\hline 37 & 39 & 0,268 & Sulit & 6 & 14 & 6 & 14 \\
\hline 38 & 38 & 0,236 & Sulit & 4 & 13 & 2 & 12 \\
\hline 39 & 37 & 0,216 & Sulit & 2 & 12 & 3 & 12 \\
\hline 40 & 18 & 0,209 & Sulit & 0 & 13 & 0 & 13 \\
\hline \multicolumn{4}{|c|}{ Correlation } & 0,63 & 0,608 & 0,621 & 0,591 \\
\hline
\end{tabular}


Tabel 12 juga memberi informasi tentang kekurangtepatan estimasi beberapa butir oleh para panelis. Kekurangtepatan estimasi butir oleh para panelis itu terlihat kongruen baik pada metode Extended Angoff maupun pada metode Ebel. Butir-butir tersebut adalah butir nomor13, 19, 21, 31, 32, dan 36. Para panelis baik pada pada metode Extended Angoff maupun metode Ebel menganggap butir nomor 13, 19, 21, 31, dan 32 sulit sementara secara statistik butir terse-but termasuk dalam tingkat kesulitan se-dang. Begitu pula sebaliknya, para panelis baik pada pada metode Extended Angoff maupun metode Ebel menganggap butir no-mor 36 mudah sementara secara statistik bu-tir tersebut termasuk dalam butir yang sulit.

Jika kita bandingkan nilai korelasinya, terlihat bahwa metode Extended Angoff memiliki nilai korelasi lebih tinggi dibanding metode Ebel baik pada putaran 1 maupun putaran 2. Ini menunjukkan bahwa konsistensi intra-judge dalam masing-masing putaran pada metode Extended Angoff lebih baik dibanding metode Ebel. Atau dengan kata lain, panelis pada metode Extended Angoff lebih konsisten dalam melakukan penjurian di dalam setiap putaran dibanding panelis pada metode Ebel.

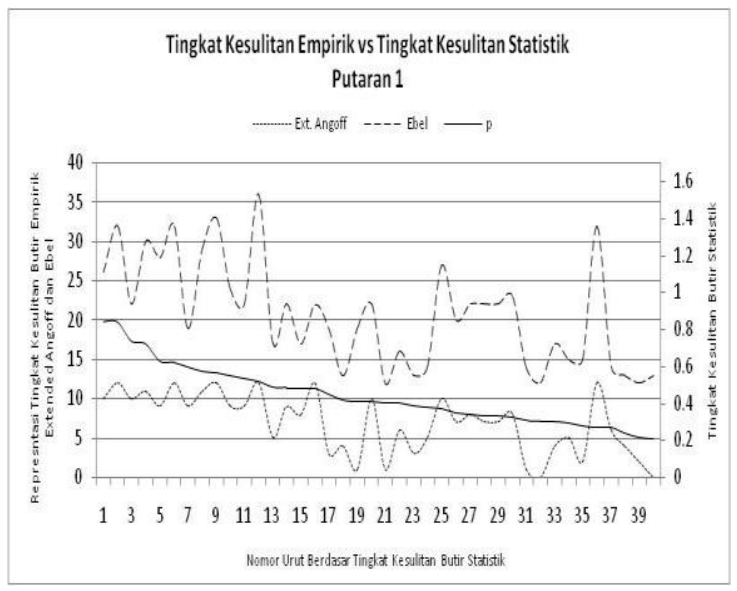

Gambar 1. Pemetaan Tingkat Kesulitan Butir Statistik dan Representasi Tingkat Kesulitan Butir Empirik Metode Extended Angoff dan Metode Ebel Putaran 1
Kesimpulan di atas juga terlihat jelas pada Gambar 1 dan Gambar 2. Pada kedua gambar tersebut sumbu aksis menunjukkan nomor urut berdasar tingkat kesulitan butir secara statistik. Sumbu ordinat mayor menunjukkan representasi tingkat kesulitan butir secara empirik untuk metode Extended Angoff dan metode Ebel, sementara sumbu ordinat minor menunjukkan tingkat kesulitan butir secara statistik (p).

Pada kedua gambar, baik Gambar 1 maupun Gambar 2 terlihat bahwa grafik tingkat kesulitan butir secara statistik bergerak secara tenang (garis tidak putus-putus) sementara grafik representasi tingkat kesulitan butir secara empirik baik pada metode Extended Angoff maupun metode Ebel bergerak secara fluktuatif (garis putus-putus pendek dan panjang). Namun demikian, dari kedua gambar tersebut terlihat juga bahwa grafik nilai representasi tingkat kesulitan butir secara empirik pada metode Ebel selalu lebih fluktuatif dibanding metode Extended Angoff. Hal inilah yang menjelaskan mengapa nilai korelasi pada metode Ebel selalu lebih rendah dibanding nilai korelasi pada metode Extended Angoff. Fluktuasi nilai ini berbanding terbalik dengan tingkat konsistensi penjurian. Semakin fluktuatif berarti semakin tidak konsisten.

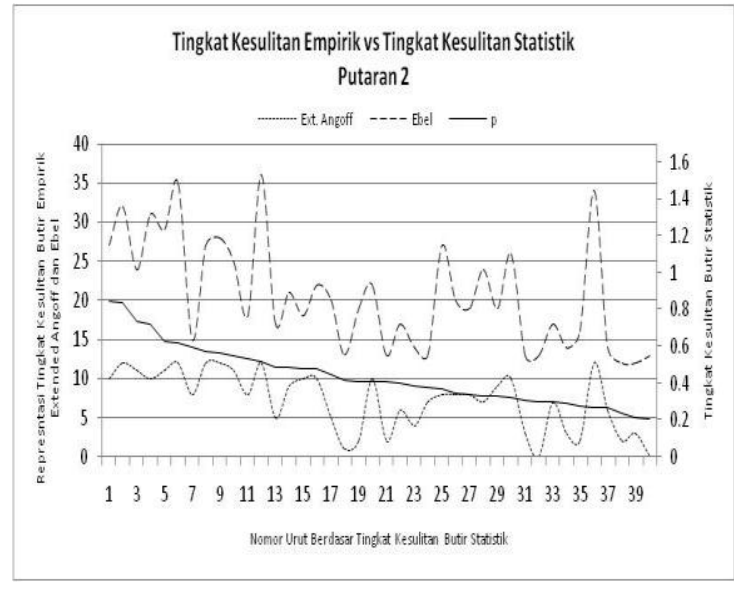

Gambar 2. Pemetaan Tingkat Kesulitan Butir Statistik dan Representasi Tingkat Kesulitan Butir Empirik Metode Extended Angoff dan Metode Ebel Putaran 2 
Inter-judge consistency dilihat dari simpangan baku cutscore. Tabel 13 memperlihatkan simpangan baku cutscore panelis pada metode Extended Angoff dan metode Ebel. Tabel 13 tersebut menunjukkan bahwa simpangan baku cutscore metode Extended Angoff selalu lebih kecil dibanding metode Ebel baik pada putaran 1, putaran 2, maupun gabungan putaran 1 dan 2. Hal itu mengindikasikan bahwa inter-judge consistency metode Extended Angoff selalu lebih baik dibanding metode Ebel. Dengan kata lain rating cutscore individual masing-masing panelis pada metode Extended Angoff selalu lebih konsisten dibanding rating cutscore individual masing-masing panelis pada metode Ebel baik pada putaran 1 maupun putaran 2.

Tabel 13. Simpangan Baku Penjurian Metode Extended Angoff dan Metode Ebel

\begin{tabular}{ccc}
\hline \multirow{2}{*}{ Putaran } & \multicolumn{2}{c}{ Simpangan Baku } \\
\cline { 2 - 3 } & Ext. Angoff & Ebel \\
\hline Pertama & 3,977 & 6,476 \\
Kedua & 4,243 & 5,740 \\
Total & 4,054 & 6,003 \\
\hline
\end{tabular}

Jika kedua metode tersebut dibandingkan, manakah yang lebih disarankan atau direkomendasikan untuk digunakan? Penelitian ini menyimpulkan metode Extended Angoff lebih disarankan dibanding metode Ebel. Argumen yang mendasari rekomendasi itu adalah sebagai berikut:

Pertama, metode Extended Angoff memiliki prosedur yang relatif lebih mudah dibanding metode Ebel. Kemudahan ini di antaranya berkenaan dengan estimasi yang harus dilakukan oleh para panelis. Bagi panelis tentunya lebih mudah membuat estimasi untuk tiap butirnya dibanding membuat estimasi untuk tiap sel yang di dalamnya bersarang beberapa butir. Kemudahan lainnya adalah berkenaan dengan prosedur setelah estimasi. Pada metode Extended Angoff, untuk memperoleh cutscore panelis tinggal menjumlahkan banyaknya skor 1 yang dituliskan. Sementara pada metode Ebel, para panelis terlebih dahulu harus mengalikan banyaknya butir dan proporsi yang tersarang pada tiap selnya, baru kemudian menjumlahkan hasil perkalian dari 12 sel yang ada tersebut.

Kedua, metode Extended Angoff membutuhkan waktu yang relatif lebih sedikit dibandingkan metode Ebel. Pada metode Extended Angoff para panelis hanya diminta membuat estimasi satu kali banyak butir soal. Estimasi itu hanya mengenai mampu atau tidaknya siswa dalam menjawab benar suatu butir. Sementara pada metode Ebel para panelis diminta setidaknya membuat estimasi dua kali jumlah butir soal. Dua jenis estimasi itu mengenai tingkat kesulitan dan tingkat relevansi butir. Di samping itu panelis juga masih harus menentukan estimasi proporsi butir terjawab benar untuk 12 sel yang ada. Selain itu tahapan sesudah estimasi pada metode Ebel membutuhkan waktu yang lebih banyak dibanding metode Extended Angoff.

Ketiga, tingkat akurasi nilai proporsi metode Extended Angoff cenderung lebih tinggi dibanding metode Ebel. Sebab pada metode Extended Angoff proporsi ditentukan untuk setiap butirnya sementara pada metode Ebel, nilai proporsi ditentukan untuk setiap selnya. Hal ini membawa implikasi nilai proporsi pada metode Ebel kemungkinan lebih bias dibanding nilai proporsi pada metode Extended Angoff.

\section{Umpan Balik Panelis}

Dengan menggunakan metode Extended Angoff diperoleh cutscore 59 sementara dengan menggunakan metode Ebel diperoleh cutscore 50,98 pada skala 100. Hasil ini menunjukkan bahwa batas KKM kelas VIII jenjang SMP/MTs untuk mata pelajar-an Matematika di Kabupaten Sleman yang diperoleh dalam penelitian ini lebih rendah dibanding skor KKM yang biasanya ditetapkan oleh sekolah. Sebagaimana pernyataan para panelis, skor KKM mata pelajaran Matematika kelas VIII tahun ajaran 2011/2012 yang ditetapkan oleh sekolah sampel ada di kisaran nilai 70-80. Temuan ini sangat menarik karena perbedaan skor KKM yang dihasilkan cukup signifikan. Ada beberapa penyebab yang bisa diuraikan untuk menginterpretasi perbedaan tersebut. 
Penyebab pertama adalah baik metode Extended Angoff maupun metode Ebel, keduanya menggunakan perangkat tes sebagai dasar penentuan cutscore. Hal ini membawa implikasi terhadap tinggi rendahnya nilai cut-score yang dihasilkan. Pada metode Ebel tingkat kesulitan dan tingkat relevansi butir akan berpengaruh langsung pada keputusan panelis dalam menuliskan jumlah butir yang tersarang dalam tiap-tiap sel. Sementara pada metode Extended Angoff tingkat kesulitan butir akan berpengaruh langsung terhadap keputusan Ya/Tidak panelis untuk setiap butirnya. Jika instrumen tes cenderung sulit maka nilai cutscore yang dihasilkan akan cenderung rendah. Mengacu pada rata-rata proporsi jawaban benar (rata-rata P) yang ter-letak di nilai 0,441 dapat disimpulkan bahwa tingkat kesulitan instrumen ini masih dalam kategori normal, namun cenderung ke sulit. Oleh karenanya menjadi logis dan rasional jika nilai cutscore yang dihasilkan dalam penelitian ini menjadi cenderung rendah.

Penyebab yang kedua adalah kemampuan dari peserta tes. Kemampuan peserta tes ini juga berimplikasi langsung terhadap nilai cutscore yang dihasilkan. Pada metobe Ebel kemampuan peserta tes akan berpengaruh langsung pada keputusan panelis dalam menuliskan persentase butir yang bisa dijawab dengan benar oleh siswa yang ter-sarang dalam tiap-tiap sel. Sementara pada metode Extended Angoff kemampuan peser-ta tes kemampuan peserta tes akan berpe-ngaruh langsung terhadap keputusan $\mathrm{Ya} /$ Tidak panelis untuk setiap butirnya. Jika ke-mampuan peserta tes cenderung tinggi maka nilai cutscore yang dihasilkan pun akan cen-derung tinggi. Mengacu kepada hasil statistik deskriptif skor peserta tes dapat disimpulkan bahwa kemampuan peserta tes cenderung rendah. Oleh karenanya menjadi beralasan jika cutscore yang dihasilkan pun menjadi cenderung rendah.

Sebab yang ketiga adalah posisi independen para panelis. Sebagaimana pernyataan para panelis, posisi mereka yang independen dalam penelitian ini memungkinkan mereka bisa melepaskan diri dari kepentingan di luar kepentingan nonakademis. Inde- pendensi ini berimplikasi langsung terhadap ke-putusan-keputusan panelis dalam memberikan jawaban Ya/Tidak pada metode Extended Angoff maupun dalam pengisian jumlah butir dan persentase sel pada metode Ebel. Posisi independen panelis ini menjadi penting sebab sebagaimana diketahui, para guru di sekolah biasanya diminta menetap-kan skor KKM tidak untuk kepentingan akademis semata namun lebih untuk kepentingan nonakademis. Sudah menjadi rahasia umum bahwa skor KKM yang ditetapkan guru di sekolah biasanya merupakan pesanan birokrasi pendidikan. Pesan itu berupa tuntutan skor KKM minimal 70 agar sekolah bisa dianggap telah melaksanakan Standar Nasional Pendidikan terutama Standar Penilaian. Jadi adanya patokan itu menyebabkan guru sering sekedar mematut-matut skor pada tiga aspek penentu KKM agar skor KKM lebih atau sama dengan 70. Itulah mengapa ketika guru diberikan kebebasan untuk memberikan penilaian maka muncul nilai cutscore yang lebih rendah dari KKM yang telah mereka tetapkan di sekolah.

Kualitas penyelenggaraan pertemuan standard setting diukur melalui survei dengan membagikan angket kepada para panelis setelah penentuan cutscore selesai. Angket itu digunakan untuk mendapat umpan balik peserta menyangkut 4 komponen utama yaitu fasilitas, penyelenggaraan, pemahaman materi, dan refleksi atas pertemuan standard setting yang telah dilakukan. Setiap panelis diminta memberikan tanggapan sikapnya atas setiap pernyataan yang ada di dalam angket.

Pada bagian pertama angket, panelis diminta memberikan tanggapannya terhadap tempat pertemuan, suasana pertemuan, dan fasilitas modul kegiatan. Berdasarkan rekap hasil angket, semua panelis baik pada metode Extended Angoff maupun pada metode Ebel menyatakan bahwa tempat dan suasana pertemuan standard setting cukup kondusif, nyaman, dan memadai. Selain itu, meskipun ada beberapa panelis yang merasa ragu namun mayoritas panelis menyatakan bahwa modul kegiatan yang diberikan mampu memberikan pemahaman yang memadai 
tentang standard setting serta metode yang digunakan. Feedback ini berguna untuk memerbaiki kualitas modul yang digunakan jika dilakukan pertemun sejenis pada waktu yang akan datang.

Tanggapan panelis memperlihatkan bahwa kegiatan Pemaparan Materi mampu memberi pemahaman yang memadai terhadap pengertian standard setting berikut metode Extended Angoff dan Ebel yang digunakan. Begitu pula halnya dengan kegiatan Pelatihan. Seluruh panelis baik pada metode Extended Angoff maupun metode Ebel menyatakan bahwa kegiatan Pelatihan mampu memberi pemahaman dan pengalaman yang memadai tentang standard setting berikut metode Extended Angoff dan metode Ebel yang digunakan. Tanggapan ini memberi informasi tentang pentingnya kegiatan Pemaparan Materi berikut Pelatihan dalam membangun pemahaman yang utuh dan pengalaman yang memadai tentang metode standard setting yang hendak digunakan. Kedua kegiatan ini merupakan bagian dari validitas prosedural yang dapat berimplikasi langsung terhadap validitas internal cutscore yang dihasilkan.

Tahap selanjutnya setelah dua kegiatan di atas adalah kegiatan Mengerjakan Soal. Kegiatan ini dimaksudkan untuk memberi gambaran yang memadai kepada panelis tentang tingkat kesulitan butir yang digunakan dalam penentuan cutscore. Tujuan ini ternyata sejalan dengan pernyataan para panelis yang merasa sangat terbantu dalam mendapatkan gambaran tentang tingkat kesulitan butir melalui kegiatan Mengerjakan Soal. Pada metode Ebel, kegiatan Mengerjakan Soal ternyata juga sangat membantu panelis dalam memperoleh gambaran yang memadai tentang tingkat relevansi soal.

Rekapitulasi tanggapan panelis juga menunjukkan bahwa instruksi-instruksi yang diberikan dalam penentuan cutscore cukup jelas dan mudah dipahami oleh para panelis baik pada metode Extended Angoff maupun metode Ebel. Hal ini kemungkinan disebabkan oleh pemahaman yang bagus dari para panelis tentang standard setting berikut metode yang digunakan.
Selain itu, dari sisi waktu, para panelis menyatakan bahwa mereka merasa cukup puas dengan alokasi waktu dalam kegiatan pertemuan standard setting ini. Sebagian besar panelis baik pada metode Extended Angoff maupun Ebel menyatakan mendapat alokasi waktu yang cukup memadai baik untuk kegiatan diskusi maupun untuk menyelesaikan tugas-tugas individual mereka.

Berdasarkan tanggapan panelis diketahui bahwa setelah mengikuti kegiatan Pemaparan Materi dan Pelatihan, para panelis memiliki pemahaman yang memadai tentang standard setting berikut tahapan-tahapan yang ada dalam metode Extended Angoff dan metode Ebel. Karena mereka memiliki pemahaman yang memadai maka mereka tidak merasa kesulitan mengikuti tahapantahapan yang ada dalam metode Extended Angoff dan metode Ebel.

Sebagai guru senior yang memiliki pengalaman mengajar matematika lebih dari 10 tahun, para panelis menyatakan memiliki pemahaman yang memadai tentang kemampuan akademis siswa-siswinya di sekolah. Selain itu mereka juga merasa cukup familiar dengan jenis-jenis soal berikut deskriptor masing-masing butir soal yang ada dalam instrumen tes yang digunakan dalam penentuan standard setting. Hampir seluruh panelis pada metode Extended Angoff menyatakan tidak mengalami kesulitan dalam menentukan keputusan-keputusan butir. Begitu pula para panelis pada metode Ebel, yang sebagian besar menyatakan tidak mengalami kesulitan dalam menentukan tingkat kesukaran maupun tingkat relevansi butir serta tidak mengalami kesulitan dalam menentukan proporsi jawaban butir pada setiap selnya. Pernyataan itu mengidikasikan bahwa para panelis memang benar-benar telah memiliki pemahaman yang memadai tentang standard setting berikut tahapantahapan yang ada dalam metode Extended Angoff dan metode Ebel. Oleh karena itu, sebagian besar panelis menyatakan memiliki kepercayaan yang tinggi terhadap keputusan-keputusan yang diambil yang digunakan untuk menentukan cutscore individual mereka masing-masing. 
Bagian keempat dari angket ini adalah angket refleksi. Melalui angket refleksi ini hendak dijaring pendapat panelis mengenai penentuan KKM dengan menggunakan metode konvensional dan penentuan KKM dengan menggunakan metode standard setting. Rekapitulasi terhadap hasil angket tersebut menginformasikan bahwa kegiatan penentuan cutscore dengan menggunakan metode standard setting ini merupakan pengalaman pertama mereka. Tak satu pun panelis yang menyatakan pernah melakukan hal serupa sebelumnya. Standard setting ini merupakan hal yang baru bagi mereka dan merupakan pengalaman pertama mereka, namun mereka tidak merasa kesulitan mengikuti dan menyelesaikan tahapan-tahapannya. Itulah mengapa sebagian besar mereka berpendapat bahwa guru-guru senior lain di luar kegiatan ini akan mampu menggunakan metode Extended Angoff maupun metode Ebel jika diberi pemahaman terlebih dahulu. Pernyataan ini mengindikasikan bahwa kedua metode tersebut cukup kompatibel bagi para guru untuk digunakan dalam penentuan KKM.

Selain itu, hasil rekapitulasi tersebut juga memberikan informasi bahwa semua guru pernah menentukan KKM dengan menggunakan metode konvensional di sekolah masing-masing. Sebagian besar dari mereka baik pada metode Extended Angoff maupun metode Ebel menyatakan mengalami kesulitan dalam menentukan skor untuk intake, daya dukung, dan kompleksitas. Itulah mengapa sebagian besar dari mereka setuju bahwa patokan keputusan yang digunakan metode Extended Angoff dan Ebel lebih pasti dibanding patokan skor yang digunakan pada metode konvensional.

Jika dilihat dari sisi penggunaan metode, para panelis menyatakan bahwa penggunaan metode Extended Angoff dan Ebel lebih memudahkan mereka dalam penentuan KKM dibanding saat menggunakan metode konvensional. Pada saat menggunakan metode konvensional para panelis menyatakan sering merasa bingung ketika diminta menentukan skor masing-masing komponen. Kebingungan itu kemungkinan bersumber dari dua hal. Pertama, dari belum adanya acuan penilaian untuk masing-masing komponen yang digunakan. Kedua, bersumber dari terlalu banyaknya faktor yang harus dipertimbangkan ketika memberikan skor untuk masing-masing komponen tersebut. Oleh karena itu, mereka menganggap bahwa hasil KKM dengan menggunakan metode Extended Angoff dan metode Ebel lebih argumentatif dibanding KKM yang dihasilkan dengan menggunakan metode konvensional.

\section{Simpulan dan Saran}

Simpulan

Kesimpulan yang bisa diperoleh dari penelitian ini adalah sebagai berikut.

Pertama, analisis butir soal dengan menggunakan teori tes klasik menunjukkan bahwa semua butir dalam soal UKK jenjang SMP/MTs kelas VIII mata pelajaran Matematika Kabupaten Sleman tahun pelajaran 2011/2012 bisa diterima atau diikutkan dalam penentuan cutscore menggunakan metode Extended Angoff dan metode Ebel.

Kedua, cutscore yang diperoleh metode Extended Angoff adalah 59 sedangkan metode Ebel adalah $\mathbf{5 0 , 9 8}$ pada skala $\mathbf{1 0 0}$. Cutscore ini berbeda secara signifikan dengan KKM sekolah yang ditentukan dengan menggunakan metode konvensional.

Ketiga, KKM metode Extended Angoff, menghasilkan persentase ketuntasan $19 \%$ sementara KKM metode Ebel menghasilkan persentase ketuntasan $\mathbf{2 8 \%}$. Kecilnya angka persentase ketuntasan ini menunjukkan bahwa para panelis memiliki estimasi yang terlalu tinggi terhadap kemampuan akademis siswa-siswinya.

Keempat, penelitian ini menunjukkan bahwa ada 38 deskriptor kemampuan Matematika siswa kelas VIII jenjang SMP/MTs di kabupaten Sleman yang telah dikatakan tuntas jika menggunakan skor KKM berdasarkan metode Extended Angoff.

Kelima, berdasarkan analisis terhadap internal validity of standard setting dapat disimpulkan bahwa metode Extended Angoff memberikan hasil yang relatif lebih valid dibanding metode Ebel.

Keenam, metode Extended Angoff dan metode Ebel cukup kompatibel bagi 
para guru untuk digunakan dalam penentuan KKM karena guru mampu menggunakan kedua metode tersebut tanpa mengalami kesulitan dan kedua metode tersebut tidak membutuhkan dukungan analisis butir soal yang rumit.

Ketujuh, berdasarkan pendapat panelis, metode Extended Angoff dan metode Ebel lebih mudah digunakan untuk menentukan KKM dibandingkan dengan metode konvensional yang telah digunakan oleh para guru selama ini karena memiliki patokan estimasi yang lebih pasti.

Saran

Berdasarkan hasil penelitian dan mempertimbangkan beberapa keterbatasan dalam penelitian ini maka dapat disampaikan saran sebagai berikut.

Pertama, penggunaan cara konvensional dalam penentuan KKM perlu ditinjau dan dikaji ulang karena penentuan KKM dengan menggunakan metode Extended Angoff dan metode Ebel menghasilkan skor yang lebih argumentatif dan lebih bisa dipertanggungjawabkan.

Kedua, perlu dilakukan upaya untuk mendapatkan skor KKM tingkat kabupaten/kota menggunakan metode yang ada dalam standard setting. Skor KKM tingkat kabupaten/kota itu bisa digunakan sebagai acuan bagi sekolah ketika menentukan skor KKM sekolah.Penelitian ini menyimpulkan metode Extended Angoff lebih disarankan untuk digunakan dibandingkan dengan metode Ebel.

Ketiga, perlu dilakukan diseminasi di kalangan guru mengenai penentuan KKM dengan menggunakan metode yang ada dalam standard setting terutama metode Extended Angoff.

Keempat, perlu digunakannya KKM dalam pertimbangan penyusunan perencanaan, desain, dan strategi pembelajaran pada suatu jenjang pendidikan untuk membantu mencapai target kelulusan yang akan ditetapkan.

Kelima, perlu mulai dipikirkan digunakannya beberapa level cutscore sekaligus pada suatu kelas tertentu untuk membantu memetakan hasil pembelajaran.

\section{Daftar Pustaka}

Alderson, J.C. (1993). Judgements in language testing. In D. Douglas C. Chapelle (Eds), A new decade of language testing research (pp.46-57). Alexandria, VA: TESOL

Athanasou, J. A., Lamprianou, I. (2009). A teacher's guide to educational assessment. Rotterdam: Sense Publishers.

Cizek, G. J. \& Bunch, B. B. (2007). Standard setting: a guide to establishing and evaluating performance standard on test. ND: Sage Publications

Cohen, A. S., Kane, M. T., \& Crooks, T. J. (1999). A generalized examinee-centered method for setting standard on achievement test [Versi Elektronik]. Applied Measurement in Education, 12(4),

Ebel, Robert L. (1979). Essentials of educational measurement. New Jersey: PrenticeHall.

Fowell, S.L., Fewtrell, R., \& McLaughlin, P.J. (2008) Estimating the minimum number of judges required for test-centered standard setting on written assessments. Do discussion and iteration have an influence? Advances in Health Sciences Education: Theory and Practice, 13 (1): 11-24.

Loomis, S.C., Hanick, P.L., Bay,L., \& Crouse, J.D. (2000). Developing achievement levels for the 1998 NAEP in civics interim report: field trials. ACT, Inc.

Norcini, J.J., Lipner, R.S., Langdon, L.O., \& Streeker, C.A. (1987). A comparison of three variations on standard-setting method. Journal of Educational Measurement, 24 (1), 56-64.

Reynolds, C. R., Livingston, R. B., Willson, V. (2010). Measurement and assessment in education $\left(2^{\text {nd }}\right.$ ed). New Jersey: Pearson Education, Inc.

Stahl, John A. (2008). Standard setting methodologies: Strengths and weaknesses., http://www.iaea2008.cambridgeasses sment.org.uk/ca/digitalAssets/18050 2_Stahl.pdf.

Wells, C. S. (2007). Makalah kuliah umum. Yogyakarta. 